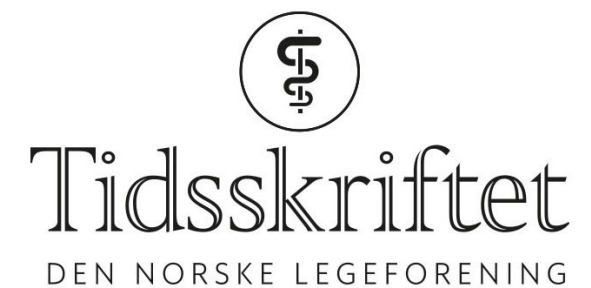

DEN NORSKE LEGEFORENING

\title{
For lang saksbehandlingstid i enkeltsaker
}

KOMMENTAR

\section{LISBETH HOMLONG}

E-post:1ho@helsetilsynet.no

Lisbeth Homlong er seniorrådgiver i Statens helsetilsyn

\section{JAN FREDRIK ANDRESEN}

Forfatterne har ikke oppgitt noen interessekonflikter.

I en kommentar publisert 14. oktober 2019 stiller Erlend Hem flere spørsmål til Statens helsetilsyn som gjelder saksbehandlingen i tilsynssaker (1). Som vi skrev i vårt innlegg av 19. september 2019, har vi fullt ut tatt innover oss at saksbehandlingstiden i den aktuelle saken omtalt i Tidsskriftet 2. august 2019 var altfor lang, og vi har beklaget det $(2,3)$. Det er vår praksis at alvorlige saker som denne skal prioriteres.

Vi er videre godt kjent med forskningen som omhandler forhøyet selvmordsrate hos leger og at tilsynssaker er en risikofaktor. Vår klare målsetning er å ivareta leger og annet helsepersonells rettssikkerhet $\mathrm{i}$ tilsynssaker, samtidig som vi utfører vårt samfunnsoppdrag.

Når det gjelder Hems konkrete spørsmål vedrørende vår saksbehandling, så kan vi svare følgende:

(a) Saksbehandlingstid er en sentral del av våre kvalitetskrav og framgår av forvaltningsloven (4). Stortinget bestemmer krav til saksbehandlingstid, og kravet til saksbehandlingstid fremgår hvert år av statsbudsjettet og embetsoppdraget til fylkesmannen. Fylkesmannsembetene og Statens helsetilsyn har som mål at median saksbehandlingstid ikke skal være mer enn henholdsvis 5 og 6 måneder. Enkelte saker kan likevel ta vesentlig lengre tid.

(b) I det løpende arbeidet med tilsynssaker har vi et kontinuerlig fokus på saksbehandlingstid. Ansvaret ligger på ledernivå i vår organisasjon. Ved hjelp av vårt elektroniske styringsverktøy holder vi oversikt over saksomfanget og i våre tertialrapporter er saksbehandlingstid alltid et sentralt tema. Våre saksbehandlere følges opp med regelmessige saksgjennomganger, og prioritering av saker er en sentral del av denne oppfølgingen.

(c) Vi tilstreber rask og effektiv saksbehandling og vår målsetning vil alltid være å overholde saksbehandlingsfristene som Stortinget har fastsatt. Per i dag er median saksbehandlingstid i samsvar med kravet fra Stortinget. I enkeltsaker kan imidlertid saksbehandlingstiden bli uforholdsmessig lang, noe som var tilfelle i saken omtalt i Tidsskriftet 2. august (3). 
(d) Som hovedregel er saksbehandlingen i forvaltningen skriftlig. Helsepersonell skal varsles per brev når frister ikke overholdes. I våre brev oppgis navn og direkte telefonnummer til saksbehandlerne, og helsepersonell som får en tilsynssak mot seg, er velkommen til å ta kontakt per telefon ved behov for informasjon om saksgangen.

Når det gjelder alvorlige saker og saker der vi ser at saksbehandlingstiden kan bli uforholdsmessig lang, er det særlig viktig med god informasjon til involvert helsepersonell.

\section{LITTERATUR:}

1. Hem E. En tyngende opplevelse? Tidsskr Nor Legeforen 2019; 139. doi:10.4045/tidsskr.19.o688. [CrossRef]

2. Homlong L, Andresen JF. Saksbehandlingstiden i tilsynssaker. Tidsskr Nor Legeforen 2019; 139. doi: 10.4045/tidsskr.19.0614. [PubMed][CrossRef]

3. Anonym . Klager fra pasienter må håndteres bedre. Tidsskr Nor Legeforen 2019; 139. doi: 10.4045/tidsskr.19.0356. [CrossRef]

4. LOV-2018-o6-22-83. Lov om behandlingsmåten i forvaltningssaker (forvaltningsloven). https://lovdata.no/dokument/NL/lov/1967-02-10 Lest 7.11.2019.

Publisert: 9. desember 2019. Tidsskr Nor Legeforen. DOI: 10.4045/tidsskr.19.0741

(C) Tidsskrift for Den norske legeforening 2020. Lastet ned fra tidsskriftet.no 